\title{
Assessment on Biocides Bioaccumulation in Mullet Liza klunzingeri in Kuwaiti Waters, off the Arabian Gulf
}

\author{
AH Bu-Olayan and BV Thomas \\ POB 5969, Department of Chemistry, Kuwait University, Kuwait
}

\begin{abstract}
Biocides, such as formaldehyde ( $\mathrm{HCHO})$, sodium hypochlorite $(\mathrm{NaOCl})$ and glutaraldehyde $\left(\mathrm{C}_{5} \mathrm{H}_{8} \mathrm{O}_{2}\right)$ that are commonly used in thermal, desalination and power plants and industries were tested on the commercially important mullet fish, Liza klunzingeri to determine the environmental contamination in the stressed ecosystem of Kuwait Bay sites. Multi-factor Probit analysis toxicity tests (96 h) on L. klunzingeri showed the lowest observed effective concentration (LOEC) and median lethal concentration $\left(\mathrm{LC}_{50}\right)$ with $\mathrm{NaOCl}\left(0.019\right.$ and $\left.0.027 \mu \mathrm{g} \mathrm{L}^{-1}\right)$ followed by $\mathrm{HCHO}(0.058$ and 0.157 $\left.\mu \mathrm{g} \mathrm{L}{ }^{-1}\right)$ and $\mathrm{C}_{5} \mathrm{H}_{8} \mathrm{O}_{2}\left(0.056\right.$ and $\left.0.072 \mu \mathrm{g} \mathrm{L}^{-1}\right)$. Site-wise analysis in the absence of feed showed high biocides toxicity in L. klunzingeri reared in seawater from Site I when compared to Sites II-III. Experiments were conducted (2-9 months) by rearing fish separately in seawater collected from three Kuwait Bay sites to test the bio-accumulated toxicity levels at LOEC of biocides fed fish using Feed Conversion Ratio (FCR) calculation. The lowest FCR was observed in fish fed with biocides in the sequence of $\mathrm{NaOCl}(0.40-1.1)$ followed by $\mathrm{C}_{5} \mathrm{H}_{8} \mathrm{O}_{2}(0.91-1.2)$ and $\mathrm{HCHO}(0.92-1.3)$ as well as with fish reared in seawater from Site I followed by Site II and Site III. High FCR was recorded in control (1.2-1.6) without the addition of biocides. These results exemplify the use of L. klunzingeri as an indicator species and may characterize a better quantification of biocides bioaccumulation using FCR calculation in mullet fish.
\end{abstract}

Key words: FCR, toxicity, biocides, mullet fish

\section{INTRODUCTION}

Environmental concern over the use of biocides stems from its use in desalination, power and thermal plants, cooling water disinfectant and antifouling paints. An exhaustive literature has been made on biocides toxicity in the marine environment ${ }^{[1-3]}$. Unregulated discharges mainly from the thermal, power and desalination plants as well as from sewages caused deleterious effects to organisms in Kuwait marine environment ${ }^{[4]}$. Biocides such as glutaraldehyde $\left(\mathrm{C}_{5} \mathrm{H}_{8} \mathrm{O}_{2}\right)$, formaldehyde (HCHO) and sodium hypochlorite $(\mathrm{NaOCl})$ used mainly in the thermal and desalination plants as biocide, disinfectant, in medical application, oil and as solvents in various industries were discharged in the aquatic environment without any safety precautions ${ }^{[5-10]}$. Probit analysis and bioaccumulation factor (BAF) determined the acute toxicity tests on pollutants in fish ${ }^{[11]}$. In nature, the biocides toxicity varied in fish subjected to feeding. Therefore, experiments were conducted to determine the accumulated biocide levels using feed conversion ratio (FCR). Over the recent years, biocides such as glutaraldehyde $\left(\mathrm{C}_{5} \mathrm{H}_{8} \mathrm{O}_{2}\right)$, formaldehyde $(\mathrm{HCHO})$ and sodium hypochlorite $(\mathrm{NaOCl})$ were used in thermal, power and desalination plants (Sites I-III) in the Kuwait Bay respectively. These biocides added to the stressed ecosystem Kuwait Bay sites which was primarily affected as a result of untreated effluent discharges, fluctuating seawater variables (specifically observed in sites I-II), upwelling of water current, inorganic pollutants, influence of anthropogenic activities and harmful algal blooms (as observed in Sites II-III). The above reasons were also suspected to be the cause for mass mortality of L. klunzingeri during the years 1999 and 2001 in Kuwait Bay sites ${ }^{[12,13]}$. However, publications on L. klunzingeri as a tool to determine the bio-accumulated biocide toxicity that could be supported by Feed Conversion Ratio (FCR) calculation were limited for Kuwait Bay sites which developed differential site-specific stressed ecosystem and hence the study.

\section{MATERIALS AND METHODS}

Sampling sites: Abundantly available mullet fish, $L$. klunzingeri and seawater were collected from three commercially important Kuwait Bay sites (Sites I-III) that represented stressed ecosystem over the recent years (Fig. 1).

Site I (Subiyah) is in the Northern part of Kuwait Bay. The profile is run from shell hash beach with a very large tidal flat having Eolithic bed rock, calcareous sands pro-grading into silts and clays. This site is subjected to effluent discharges from the thermal plant. 
Site II (Doha) has a power plant. It has been affected by major oil spills discharged during the Gulf War by the Iraqis. The seabed is shallow. This site has power plant and various industries and thus demarcated as an industrialized zone of Kuwait.

Site-III (Kuwait Towers) has a desalination plant, few beach rocks and inter-tidal flats. This site is prone to domestic and industrial effluents. This location is one of the centers for recreational activities and thus found polluted with sewage wastes in the aquatic system.

Fish rearing in the laboratory: Fish (10 replicates), each weighing $20 \pm 3 \mathrm{~g}$ and total length $9 \pm 3 \mathrm{~cm}$ were acclimated separately in three aquarium tanks in the laboratory containing filtered disinfected seawater collected from three Kuwait Bay sites that served as controls. Toxicity and bioaccumulation using FCR experiments were carried out separately in fish reared in disinfected and filtered seawater $(250 \mathrm{l})$ collected from three Kuwait Bay sites (I-III). The fish were fed (2\% body weight) with Grower Feed (Tetra Marin (Tetra Werke, Germany) comprising of crude protein (45\%), dry matter-dry yeast, Oat meal, shrimp meal, wheat gluten $(30 \%)$ crude fat $(6 \%)$, oil $(4.8 \%)$, crude fiber $(2 \%)$, vitamins $(0.2 \%)$, moisture $(6 \%)$ and ash $(5.1 \%)$. Seawater (5\%) was exchanged every two days. Antibiotics and fungicides were used in both test samples (before the initiation of toxicity tests) and in control.

Formaldehyde determination in seawater: Based on the concentration ranges of formaldehyde ( $\mathrm{HCHO}$ ) employed for treatment plants, test solutions ranging $0.09-0.40 \mu \mathrm{g} \mathrm{L}^{-1}$ was prepared and added to seawater in the aquarium tanks. After the preparation of the test solution, samples of $10 \mathrm{ml}$ were subjected to 4-amino3-hydrazine-5mercapto-1, 2, 4-triazole (AHMT) method $^{[5]}$ using a HP Spectrophotometer. Standard curves of $\mathrm{HCHO}(37 \% \mathrm{v} / \mathrm{v})$ reagent was used to calculate their concentrations $\left(\mu \mathrm{g} \mathrm{L}^{-1}\right)$ in seawater.

Glutaraldehyde determination in seawater: Stock solution of glutaraldehyde $\left(\mathrm{C}_{5} \mathrm{H}_{8} \mathrm{O}_{2}-26.57 \% \quad \mathrm{v} / \mathrm{v}\right)$ ranging $0.06-0.10 \mu \mathrm{g} \mathrm{L}^{-1}$ was prepared based on their usage of biocide in desalination and power plants. The test method employs a titrimetric chemistry using sulfuric acid and sodium sulfite with an end point indicator phenolphthalein $^{[14]}$.

Sodium hypochlorite determination in seawater: Test solution of sodium hypochlorite with concentrations range of $0.023-0.042 \mu \mathrm{g} \mathrm{\textrm {L } ^ { - 1 }}$ were prepared based on their levels $(5 \%)$ used as disinfectant and biocide in desalination and power plants. Following DPD (N-N Diethyl-P-Phenylenediamine) method, direct determination of hypochlorite concentrations were made as DPD compounds reacted with hypochlorite ions ${ }^{[15,16]}$.

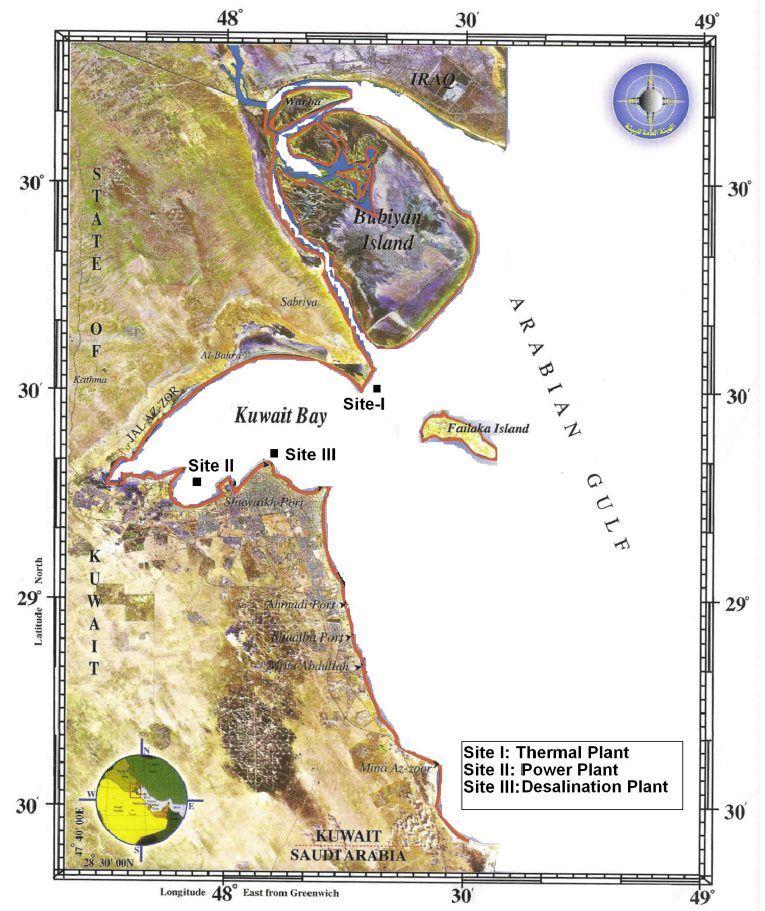

Fig. 1: Map indicating Kuwait Bay sampling sites

Acute toxicity test: L. klunzingeri replicates for toxicity tests $\left(\mathrm{LC}_{50}\right)$ were acclimated for $24 \mathrm{~h}$ in the lab. Stock solution $\left(1 \mathrm{~g} \mathrm{~L}^{-1}\right)$ of each biocide was added to each tank containing filtered seawater collected from the three sites of Kuwait Bay (Fig. 1) to produce the required $\mathrm{LC}_{50}$ test concentration ranges. Biocide solution was renewed every $24 \mathrm{~h}$ to prevent lowering of toxicant levels ${ }^{[17]}$. Tanks with fish but without the addition of biocide served as control. The $96 \mathrm{~h} \mathrm{LC}_{15}$, LC 50, LC 99 values using the Probit Program were calculated $^{[18,19]}$.

Feed conversion ratio (FCR) calculation in biocide bio-accumulated fish: Biocides bioaccumulation in fish at LOEC (lowest observed effective concentration) was assessed following the method described by ${ }^{[3]}$ through feed and subjected for a long exposure period (2-9 months). FCR was calculated as mentioned below: $\mathrm{FCR}=$ Food fed /biomass gained or dry feed $(\mathrm{Kg}) / \mathrm{wt}$. gained by fish $(\mathrm{Kg})$

\section{RESULTS AND DISCUSSION}

Seawater analysis: The present study chose biocides since they were utilized abundantly in thermal, desalination and power plants and discharged into the Bay without much treatment. Biocides concentrations of $\mathrm{NaOCl}, \mathrm{HCHO}$ and $\mathrm{C}_{5} \mathrm{H}_{8} \mathrm{O}_{2}$, were below detectable levels in the sampled seawater collected from the three classified Kuwait Bay sites (Fig. 1). Reasons could be attributed to: (1) their highly photo and biodegradable nature and upwelling water current and (2) the effect of seawater treatment used in the industrial plants before 
Am. J. Environ. Sci., 2 (3): 109-113, 2006

Table 1: Estimated exposure concentrations of biocides to Liza klunzingeri (10 replicates) using Probit Program (USEPA 1993)

\begin{tabular}{|c|c|c|c|c|}
\hline \multirow{2}{*}{$\begin{array}{l}\text { Biocides/ } \\
\text { Site }\end{array}$} & \multicolumn{3}{|c|}{ Conc. $(\mu \mathrm{g} / \mathrm{l})$ at LC point } & \multirow[t]{2}{*}{$\chi^{2}$ calculated } \\
\hline & 15 & 50 & 99 & \\
\hline \multicolumn{5}{|l|}{ Subiyah-I } \\
\hline $\mathrm{C}_{5} \mathrm{H}_{8} \mathrm{O}_{2}$ & 0.056 & 0.072 & 0.128 & $0.212 *$ \\
\hline C.I. & $(0.035-0.064)$ & $(0.061-0.079)$ & $(0.104-0.255)$ & \\
\hline $\mathrm{HCHO}$ & 0.066 & 0.157 & 1.092 & $1.339 *$ \\
\hline C.I. & $(0.018-0.103)$ & $(0.101-0.222)$ & $(0.540-11.780)$ & \\
\hline $\mathrm{NaOCl}$ & 0.019 & 0.027 & 0.053 & $1.717 *$ \\
\hline C.I. & $(0.010-0.024)$ & $(0.020-0.030)$ & $(0.043-0.112)$ & \\
\hline \multicolumn{5}{|l|}{ Doha-II } \\
\hline $\mathrm{C}_{5} \mathrm{H}_{8} \mathrm{O}_{2}$ & 0.058 & 0.074 & 0.130 & $0.044 *$ \\
\hline C.I. & $(0.039-0.066)$ & $(0.065-0.082)$ & $(0.106-0.248)$ & \\
\hline $\mathrm{HCHO}$ & 0.058 & 0.174 & 2.059 & $0.824 *$ \\
\hline C.I. & $(0.005-0.101)$ & $(0.098-0.284)$ & $(0.740-346.87)$ & \\
\hline $\mathrm{NaOCl}$ & 0.020 & 0.028 & 0.066 & $0.276^{*}$ \\
\hline C.I. & $(0.008-0.024)$ & $(0.021-0.033)$ & $(0.049-0.235)$ & \\
\hline \multicolumn{5}{|c|}{ Kuwait Towers-III } \\
\hline $\mathrm{C}_{5} \mathrm{H}_{8} \mathrm{O}_{2}$ & 0.061 & 0.083 & 0.165 & $0.293 *$ \\
\hline C.I. & $(0.036-0.070)$ & $(0.074-0.100)$ & $(0.123-0.640)$ & \\
\hline $\mathrm{HCHO}$ & 0.077 & 0.222 & 2.430 & $0.824 *$ \\
\hline C.I. & $(0.011-0.124)$ & $(0.145-0.424)$ & $(0.848-380.267)$ & \\
\hline $\mathrm{NaOCl}$ & 0.027 & 0.038 & 0.081 & $1.384 *$ \\
\hline C.I. & $(0.015-0.031)$ & $(0.033-0.048)$ & $(0.057-0.436)$ & \\
\hline
\end{tabular}

Table 2: FCR in Liza klunzingeri (10 replicates) reared in three Kuwait Bay sites and fed with and without biocides

\begin{tabular}{|c|c|c|c|c|c|}
\hline \multirow{2}{*}{$\begin{array}{l}\text { Months/ } \\
\text { Biocides }\end{array}$} & \multirow[b]{2}{*}{ Control } & \multicolumn{4}{|c|}{ FCR with biocides (feed/biomass gain) $=\mathrm{Kg}$ dry feed } \\
\hline & & Site $-\mathrm{I}$ & Site-II & Site -III & wt. gained \\
\hline $2^{\text {nd }}$ Month & 1.20 & & & & \\
\hline $\mathrm{C}_{5} \mathrm{H}_{8} \mathrm{O}_{2}$ & & 0.40 & 0.80 & 0.90 & \\
\hline $\mathrm{NaOCl}$ & & 0.42 & 0.82 & 0.91 & \\
\hline $\mathrm{HCHO}$ & & 0.45 & 0.85 & 0.92 & \\
\hline $3^{\text {rd }}$ Month & 1.20 & & & & \\
\hline $\mathrm{C}_{5} \mathrm{H}_{8} \mathrm{O}_{2}$ & & 0.45 & 0.82 & 0.92 & \\
\hline $\mathrm{NaOCl}$ & & 0.47 & 0.83 & 0.94 & \\
\hline $\mathrm{HCHO}$ & & 0.48 & 0.86 & 0.96 & \\
\hline $4^{\text {th }}$ Month & 1.40 & & & & \\
\hline $\mathrm{C}_{5} \mathrm{H}_{8} \mathrm{O}_{2}$ & & 0.47 & 0.84 & 0.93 & \\
\hline $\mathrm{NaOCl}$ & & 0.48 & 0.85 & 0.95 & \\
\hline $\mathrm{HCHO}$ & & 0.49 & 0.87 & 0.97 & \\
\hline $6^{\text {th }}$ Month & 1.44 & & & & \\
\hline $\mathrm{C}_{5} \mathrm{H}_{8} \mathrm{O}_{2}$ & & 0.52 & 0.85 & 0.94 & \\
\hline $\mathrm{NaOCl}$ & & 0.54 & 0.86 & 0.95 & \\
\hline $\mathrm{HCHO}$ & & 0.56 & 0.91 & 0.98 & \\
\hline $9^{\text {th }}$ Month & 1.60 & & & & \\
\hline $\mathrm{C}_{5} \mathrm{H}_{8} \mathrm{O}_{2}$ & & 0.59 & 0.86 & 1.10 & \\
\hline $\mathrm{NaOCl}$ & & 0.62 & 0.89 & 1.20 & \\
\hline $\mathrm{HCHO}$ & & 0.64 & 0.90 & 1.30 & \\
\hline
\end{tabular}

FCR: Feed conversion ratio; Control: FCR without biocides addition; SiteI-III: Subiyah, Doha, Kuwait Towers, $\mathrm{C}_{5} \mathrm{H}_{8} \mathrm{O}_{2}$ : glutaraldehyde, $\mathrm{NaOCl}$ : sodium hypochlorite, HCHO: formaldehyde

they were let out in the Bay. This was also validated in the present study in fish reared in seawater and subjected for $96 \mathrm{~h}$ without biocides (control) from the three Kuwait Bay sites.

Acute toxicity tests: Using Probit program ${ }^{[18]}$, the $96-\mathrm{h}$ $\mathrm{LC}_{50}$ of $L$ klunzingeri in seawater collected from Kuwait Bay sites (Fig. 1) revealed the sequence of $\mathrm{NaOCl}\left(0.027-0.038 \mu \mathrm{g} \mathrm{L}{ }^{-1}\right)<\mathrm{C}_{5} \mathrm{H}_{8} \mathrm{O}_{2}(0.072-0.083 \mu \mathrm{g}$ $\left.\mathrm{L}^{-1}\right)<\mathrm{HCHO}\left(0.157-0.222 \mu \mathrm{g} \mathrm{L} \mathrm{L}^{-1}\right)$ (Table 1). Observation revealed $L$. klunzingeri sensitive to $\mathrm{NaOCl}$ at $\operatorname{LOEC}\left(0.019 \mu \mathrm{g} \mathrm{L}^{-1}\right)$ than other biocides described in this study (Table 1). This may be attributed to the effect of chlorine compounds in the body tissues of fish when compared with other biocides and supports the earlier findings ${ }^{[20]}$. Statistical analysis revealed significance in all the biocides by Chi-square heterogeneity test (Table 1).

Biocides were found highly effective at LOEC (observed at $\mathrm{LC}_{15}$ ) and $\mathrm{LC}_{50}$ to L. klunzingeri tested with seawater collected from thermal plant (Site-I) than with power plant (Site II) and desalination (Site III) plant in the Bay (Table 1 and 2). This may be attributed to the fluctuating seawater: (a) salinities (24-30\%o) and 
(b) temperatures $\left(30^{\circ} \mathrm{C}-40^{\circ} \mathrm{C}\right)$ from the thermal plant discharges into the Bay when compared to the other sites. Nevertheless, moderate and detrimental effect of biocides was observed when L. klunzingeri was subjected to toxicity tests with seawater collected from desalination and power plants. This could be attributed to (1) the discharge of untreated brine water back into the Bay, (2) high nutrient deposition and its interaction with biocides and (3) installation of mega desalination plants causing impingement and entrainment effect to marine organisms in seawater and supports the earlier observations ${ }^{[21,22]}$. However, as these chemicals were photo and biodegradable in seawater, mass mortality of this fish was observed only when large quantities of these biocides were untreated and accidentally discharged into the Kuwait Bay.

Food conversion ratio (FCR): Calculating toxicity levels or bioaccumulation factor (BAF) determined results on acute toxicity tests and bioaccumulation of pollutants in fish ${ }^{[11]}$. However, results from such studies were limited to the accumulated effect of biocides in post-fed fish. Such limitations were overcome by determining the FCR of fish to biocide toxicity results. FCR calculations also supported fish without being killed and results validated at $\mathrm{LC}_{15}$ toxicity tests. The least FCR was found in fish treated with $\mathrm{NaOCl}$ followed by $\mathrm{C}_{5} \mathrm{H}_{8} \mathrm{O}_{2}$ and $\mathrm{HCHO}$. This could be attributed to the lethal and sustainable effects of chlorine and its residues to sensitive fish than other photo and biodegradable biocides and thus, corroborates the findings of $^{[3]}$. Furthermore, observations revealed low FCR in fish reared in seawater collected from Sites I-II when compared to FCR values from Site III samples. This clearly indicated high pollution levels in seawater where thermal and desalination plants are installed.

The above findings deduce that the selected biocides can give more toxic effects to the fish caught from the Kuwait Bay. Discharges from the thermal, desalination and power plants plant and rapid industrialization could attribute to the lethal effects on such fish and their consumers. Therefore, future toxicological investigations are recommended that characterize the use of $L$ klunzingeri as biocide indicator and to implement remedial measures to untreated pollutant discharges into the sea.

\section{ACKNOWLEDGEMENTS}

This research project (KFAS 2002-1207-01) was financially supported by the Kuwait Foundation of Advancement Studies. We also wish to extend our gratitude for the facilities rendered by the Research Administration, Kuwait University.

\section{REFERENCES}

1. Liden, L., D. Buton, L. Bonger and A. Holland, 1980. Effects of chlorobrominated and chlorinated cooling waters on estuarine organisms. J. Wat. Pollut. Contr. Fed., 52: 173-182.

2. Lewis, S., N.G. Cartwright, E. Jerman, P. Tynan, I.R. Sims and N. Wellstein, 1994. Proposed environmental quality standards for chlorine in fresh and marine waters. Report for the National Rivers Authority, R\&D Notes, pp: 332.

3. Svecevicius, G., J. Syvokiene, P. Stasiunaite and L. Mickeniene, 2005. Acute and chronic toxicity of chlorine dioxide $\left(\mathrm{ClO}_{2}\right)$ and chlorite $\left(\mathrm{ClO}^{2-}\right)$ to rainbow trout (Oncorhynchus mykiss). Environ. Sc. Pollut. Res., 12: 302-305.

4. Al-Sarawi, A., M.S. Massoud, S.R. Khader and A.H. Bu-Olayan, 2002. Recent trace metals in coastal waters of Sulaibhikhat Bay. Kuwait. Technology, 8: 27-38.

5. Jung, S.H., J.W. Kim, I.G. Jeon and Y.H. Lee, 2001. Formaldehyde residues in formalin-treated olive flounder (Paralichthys olivaceus) black rockfish (Sebastes schlegeli) and seawater. Aquaculture, 194: 253-262.

6. Leung, H., 2001. Eco-toxicology of Glutaraldehyde: Review of environmental fate and effects studies. Ecotoxicol. Environ. Saf., 49: 2639.

7. Jolibois, B., M. Guerbet and S. Vassal, 2002. Glutaraldehyde in hospital wastewater. Arch. Environ. Contamin. Toxicol., 42: 137-144.

8. Laopaiboon, L., S.J. Hall and R.N. Smith, 2003. The effect of an aldehyde biocide on the performance and characteristics of laboratory-scale rotating biological contractors. J. Biotechnol., 102: 73-82.

9. Emmanuel, E., G. Keck, J.M. Blanchard, P. Vermande and Y. Perrodin, 2004. Toxicological effects of disinfections using sodium hypochlorite on aquatic organisms and its contribution to AOX formation in hospital wastewater. Environ. Int., 30: 891-900.

10. Sano, L.L., A.M. Krueger and P.F. Landrum, 2005. Chronic toxicity of glutaraldehyde: Differential sensitivity of three freshwater organisms. Aqua. Toxicol., 71: 283-96.

11. Bu-Olayan, A.H. and B.V. Thomas 2005. Toxicity and bioaccumulation of heavy metals in mullet fish Liza klunzingeri (Mugilidae: Perciformes). Chem. Ecol., 21: 191-197.

12. Heil, C.A., P.M. Glibert, M.A. Al-Sarawi, M. Behbehani and M. Husain, 2001. A fish-killing Gymnodinium selliforme bloom in Kuwait Bay, Arabian Sea: Chronology and potential causes. Mar. Ecol. Prog. Ser., 214: 15-23. 
13. Bu-Olayan, A.H. and B.V. Thomas, 2004. Effects of trace metals, harmful algal blooms, nutrients and hydrological variables to mullet Liza klunzingeri in Kuwait Bay. Biosc. Biotechnol. Res. Asia, 2: 1-8.

14. Arnold, E.G., S.C. Lenore and A.E. Eaton, 1992. Standard method for the examination of water and wastewater. American Public Health Association, Washington, pp: 4-75.

15. United States Environment Protection Authority (USEPA), 1983. Methods for chemical analysis of water and wastes method, pp: 330.5, 3.

16. American Public Health Association (APHA), 1998. Standard Methods. 20 ${ }^{\text {th }}$ Edn., 4500-Cl G, pp: 4-63.

17. Abel, P.D. and V. Axiak, 1991. Ecotoxicology and the Marine Environment. Ellis Horwood Publisher, England, pp: 43.
18. United States Environment Protection Authority (USEPA), 1993. Statistical analysis for biological methods. http://www.epa.gov/nerleerd/stat2.htm\#probit. Pp: 1.

19. Finney, D.J., 1971. Probit Snalysis. Cambridge, MA, University Press, Cambridge.

20. Wayne, G.L. and H.Y. Ming, 1998. Introduction to Environmental Toxicology: Impacts of Chemicals upon Ecological Systems. CRC Press Inc./Lewis Publishers, Boca Raton, Florida, pp:134-138.

21. Khordagui, H., 1993. KISR activities on fish kill in the Shuaiba industrial area. Kuwait Institute for Scientific Research, Kuwait. Technical Report, pp: 4338.

22. Manna, A.J., 1994. Environmental impact of dualpurpose plants. Desal. Water Reuse, 4: 46-49. 